\title{
KEGIONAL SCIENCE AND
} ECOSYSTEM MANAGEMENT:

\section{A View from the West}

Selected for presentation at the

Sixth International Symposium

on Society and Resource Management

Penn State University • May 18-23, 1996

John V. Martin, Economist U.S. Department of the Interior Bureau of Land Management Boise, Idaho

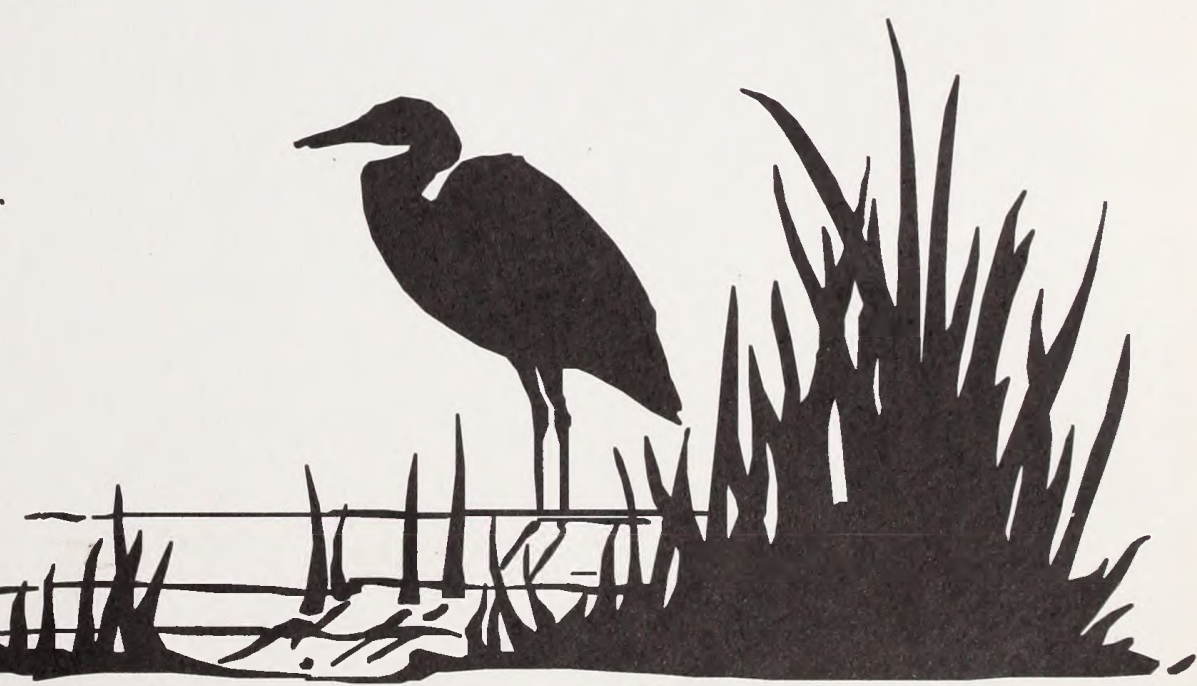





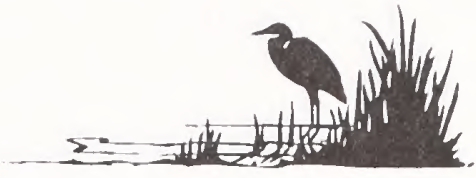

\title{
REGIONAL SCIENCE ANI) ECOSYSTEM MANAGEMENT: A View from the West
}

\begin{abstract}
The western United States is often depicted by rural landscapes where rugged individualism dominates the psyche. The history of the West has not been about sharing the natural resources dotting the landscape but in conquering through the blood, sweat, and tears of generation after generation. Administration of the public land has shifted away from conversion to private ownership to retention and management for multiple purposes beginning with the Classification and Multiple Use Act of 1964. Progressively this has lead to Ecosystem Based Management. Beyond the biological, ecological and physical aspects of Ecosystem Management, the social and economic realms tend to be the most controversial. The controversy has often been measured in emotional terms pitting timber industry jobs against spotted owls (or old growth timber) or ranching and mining jobs against salmon. All to often these controversies fall to the courts for final determination rather than remaining within the natural resource community for due deliberation and ultimate resolution. Taking a systems approach would be the natural procedural way to study (and hopefully determine) how each facet of the animate and inanimate landscape interrelates. Understanding the social, political and economic aspect of an ecosystem is perhaps more critical because of the demands the human environment places on the remainder of the ecosystem. A shared system of methodologies, models and educational tools would allow economists, sociologists and other social scientists to analyze, predict and evaluate changes to rural communities. Developing a standardized system to gather and model rural communities will enable researchers, scientists, analysts and resource managers to establish common ground with the people most likely impacted by resource decisions affecting rural communities.
\end{abstract}

\section{INTRODUCTION:}

The western United States is often depicted by rural landscapes where rugged individualism dominates the psyche. The history of the West has not been about sharing the natural resources dotting the landscape but in conquering through the blood, sweat, and tears of generation after generation. Though some families were up to the task, many did not make it beyond a winter to two. Those who remained retained exclusive use of this inhospitable land with no opposition. But once the public's land caught the attention of the general population as a potential recreational wonderland, it became apparent that these natural resources were going to be shared. Trying times were ahead for those who were not used to this new philosophy. It was particularly difficult when Johnny-come-latelys, intent on changing more than 100 years of exclusive use, wanted to place restrictions on the extraction or commercial use of these natural resources for non-use purposes. After all, who was here first!

Beginning with the Classification and Multiple Use Act of 1964, managing public land resources became a prime objective of the federal government as represented by the Bureau of Land Management (BLM). Later that decade, the National Environmental Policy Act of 1969 required all proposed federal actions be evaluated based on their potential for impacting the biological, physical and human environment. This called for documentation and determination of relation- 



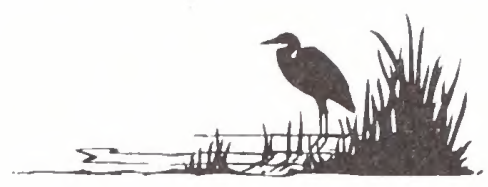

ships between natural resources and the human environment. The Federal Land Policy and Management Act of 1976, established management of all natural resources on a sustainable basis without placing undue emphasis on just a few resources. And, until recently, this philosophy has guided the management of BLM.

However, several recent environmental events changed the thinking at federal agencies. The Endangered Species Act of 1973 and subsequent amendments focused attention on the potential for populations of plant and animal species to decline or become extinct as a result of changes to their habitats. Controversy after controversy has ensued among the environmental community, commercial users of the public land and the federal land management agencies responsible for meeting the letter and spirit of the law. Within the Pacific Northwest, the northern spotted owl and selected species of salmon have dominated contemporary discussions in the field of managing the natural resources.

Beginning with the Forest Conference of April 2, 1993, convened by President Clinton, and after hearing much discussion, an interagency, interdisciplinary team of expert scientists, economists, sociologists and others was assembled - the Forest Ecosystem Management Assessment Team (FEMAT) - to develop options for managing 24 million acres of public land within the range of the northern spotted owl (the area along a corridor west of the Cascade Mountain and running north to south from the Canadian border into northern California just north of San Francisco). This resulted in the "Forest Plan for a Sustainable Economy and a Sustainable Environment Record of Decision of April 1994."

Subsequently, an effort to "develop a scientifically sound and ecosystem-based strategy for management of eastside forests" was directed by President Clinton. Through negotiations between the US Forest Service and BLM, a charter was initiated to expand and include the Interior Columbia River Basin (land east of the Cascade crest in Washington drained by the mouth of the Columbia River, which includes parts of Montana, Idaho, Wyoming, Utah and Nevada). Thus, a concerted effort has been made to apply Ecosystem Management principles on a wide scale.

Beyond the biological, ecological and physical aspects of Ecosystem Management, the social and economic realms tend to be the most controversial. Plants, animals and rocks rarely voice their opinions and never petition a representative of Congress for special consideration. It is left to humans to speak for and against these speechless (but not silent) portions of the ecosystem.

In this context it is imperative that we utilize our knowledge and skills to measure the value of these natural resources in the best way possible. This speaks volumes about our present value system and how we calculate the future worth of these resources to society and our obligation to our sons and daughters. 



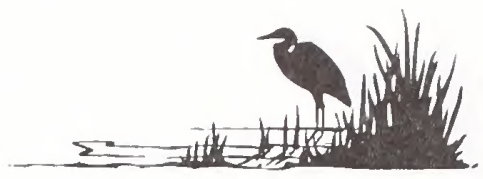

\section{THE NEW PARADIGM:}

In 1960, one in six individuals lived in the western U. S.' By 1990, that ratio had been reduced to one in five (Statistical Abstract of the United States, 1993). In fact, the human population in the intermountain west has doubled during this same 30-year period. At the same time, there has been increased emphasis on national environmental issues ${ }^{2}$ that lap over into regional and local settings. This has put considerable pressure on public land to provide for the needs of the local and regional population while balancing environmental concerns for plants, animals and the physical earth.

The controversy has often been measured in emotional terms pitting timber industry jobs against spotted owls (or old growth timber), or ranching and mining jobs against salmon. Caught in the middle are federal land management or natural resource agencies such as the United States Department of Interior Bureau of Land Management (BLM), U. S. Fish and Wildlife Service (USFWS), Bureau of Reclamation (BOC), United States Department of Agriculture Forest Service (USFS), and the United States Department of Commerce National Marine and Fisheries Service (NMFS). All too often these controversies fall to the courts for final determination rather than remaining within the natural resource community for due deliberation and ultimate resolution. Lost in all this is trying to find the balance among social values, meaningful employment and ecological integrity. Thus, the dilemma now facing our society is how to maintain a semblance of the old system while we're skyrocketing into a new society.

Utilizing multiple aspects of the economics discipline is necessary to cover the subject thoroughly. The amount of timber to cut based on cost of production and stumpage values or how much beef to produce based on production cost and prices received is but one means to evaluate the optimal utilization of resources. Another consideration is the non-consumptive use of resources through activities such as recreation. This includes rafting and kayaking wild rivers, sightseeing in wilderness areas, or the new ecotourism adventures that are springing up everywhere.

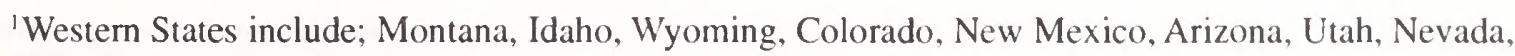
Washington, Oregon and California

${ }^{2}$ National Environmental Policy Act of 1969; Federal Water Pollution Control Act of 1972; Endangered Species Act of 1973; Comprehensive Environmental Response, Compensation, and Liability Act of 1980. 



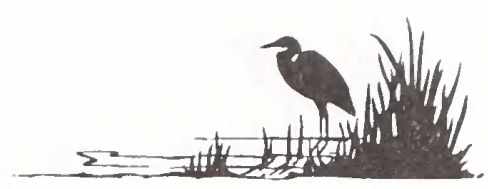

\section{REGIONAL MODELING:}

An ecosystem may encompass a small geographic area no larger than a pond or it can be as large as a continent (the late Kenneth Boulding once referred to the earth as a spaceship journeying through the Universe ${ }^{3}$. We could redefine it as an ecosystem that must regenerate in order to sustain life perpetualy). More important, a complete ecosystem portrays all aspects of life and non-life and the interaction that takes place therein. Taking a systems approach would be the natural procedural way to study (and hopefully determine) how each facet of the animate and inanimate landscape interrelates.

Understanding the social, political and economic aspect of an ecosystem is perhaps more critical because of the demands the human environment places on the remainder of the ecosystem and their ramifications. (Taking an anthropocentric view does not necessarily mean that man is the center of the universe. That view would exclude the notion of a Grand Creator to whom we have to answer for all our actions. Being a caretaker is certainly different than being the owner.) Ideally, when each part of the ecosystem puzzle is harmoniously joined together and functioning like a finely tuned metropolitan orchestra, the balance between man and his environment will have been met. Unfortunately, up to the present this has not been accomplished, even at a micro scale.

Modeling techniques in the regional sciences lend themselves well to describing the human environment in terms of relationships and dependancies between and among humans in an economic setting.

Wassily Leontief's seminal work ${ }^{4}$ describing the U. S. economy as a series of inputs and outputs is one of the great innovations toward understanding the structural make-up of economic systems. Over the years there have been refinements in data-gathering techniques and in identification of components that make up activities otherwise not identifiable. (For example recreation and tourism activities fall partly within transportation, food and kindred products, amusement, retail trade, and other sectors of the economy).

${ }^{3}$ The Economist of the Coming Spaceship Earth, Kenneth Boulding, Environmental Quality In a Growing Economy, Essays from the Sixth Resources For the Future Forum, Johns Hopkins Press, 1966.

${ }^{4}$ Wassily Leontief, "Quantitative Input-Output Relations in the Economic System of the United States," in The Review of Economics and Statistics, August 1936. 



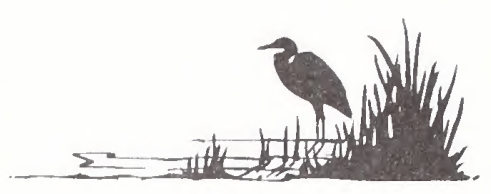

BLM, in conjunction with the USFS's Salmon National Forest, the Custer and Lemhi Counties, and the University of Idaho College of Agriculture ${ }^{5}$, have cooperatively generated social, economic and fiscal models focusing on the communities of Salmon, Tendoy, and Leadore in Lemhi County, and Challis, Mackay, and Stanley in Custer County. The objective of the models was to provide a framework for social and economic impact assessment for local and federal agency decision making concerning resources in with Custer and Lemhi Counties (see the map - Economic Subregions of Lemhi and Custer Counties, Idaho).

Based on geographic features, clustering population, and economic factors such as trading zones, the two-county region was subregionalized into seven subregions or hierarchies of influence.

These subregions generally had dominated social and economic qualities that made them unique. For example, the Pahsimeroi subregion (see map) is predominately an agricultural-based economy that is specifically dependent upon the livestock sector for both jobs and income. Most everything that is consumed (goods and services) within the subregion is purchased outside that subregion. Thus, if there is a reduction in the purchasing capability (say from a reduction in livestock AUMs off public land) from the Pahsimeroi subregion, it will have a greater impact on other subregions (such as Challis and Salmon) than it would within Pahsimeroi (or subregions, such as Stanley, which does not engage in economic trade with the Pahsimeroi subregion).

The example mentioned above can then be traced throughout the region in order to determine the full economic impact including the fiscal and social ramifications. Thus the study not only describes the current social and economic structure for the region, but it allows the analyst to portray likely outcomes based on alternative scenarios.

${ }^{5}$ This study was done under a cooperative agreement (No. D-040-A-2-006) between the above agencies and the University of Idaho, College of Agriculture. 



\section{ECONOMIC SUBREGIONS OF} LEMHI AND CUSTER COUNTIES, IDAHO

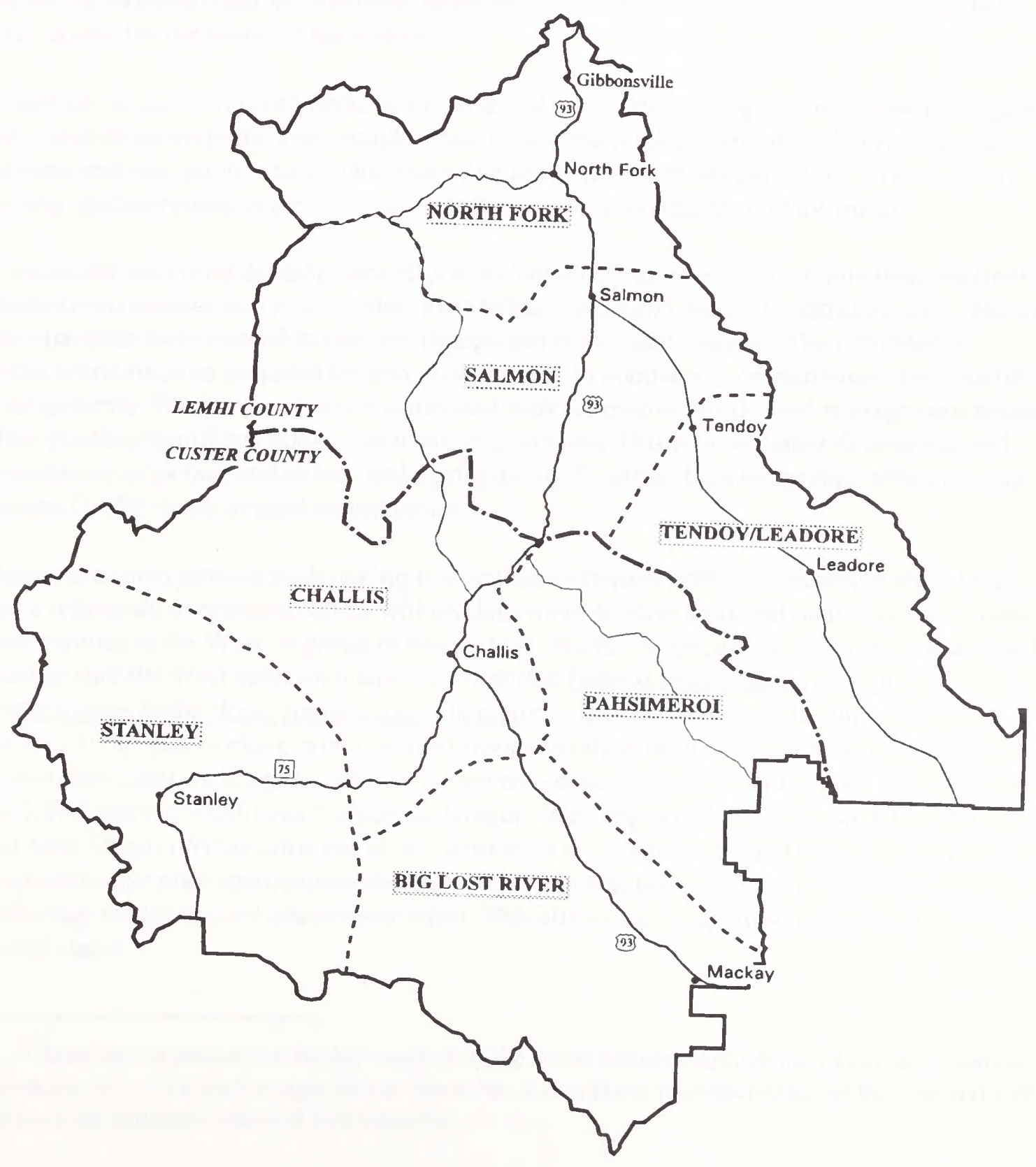





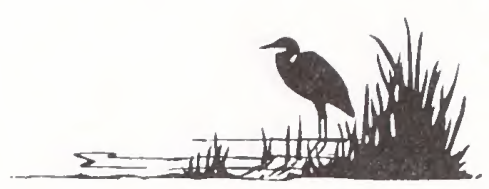

\section{RESEARCH NEEDS:}

What makes a rural community tick? Where do residents purchase goods and services not provided locally? And to what degree is the economy of a rural community dependent on the surrounding public land resources? How much pressure from local and extra local users will it take to degrade the experiences enjoyed by recreationists? These and other questions need answering to understand the condition of the human environment and to make judgments about what is best for the future of the ecosystem.

Where do we go from here? Perhaps we need a better understanding of how economic regions are linked to ecosystems. This would certainly help paint the picture of the interrelated nature of humans and their environment. One thing that needs to be understood is how an endangered salmon species relates to a community's value set (both monetarily and intrinsic).

Community $^{6}$ and rural development efforts are necessary to assist rural communities in finding alternative economic activities to alter their reliance on public lands. In addition, local leadership must have the tools needed to plan for change and to mitigate impacts. The community social fabric must be prepared for potential changes in common understandings about social arrangements. Finally, the changes associated with alternative public land management policies often produce significant conflict in local communities. This proposal intends to create and disseminate tools that will reduce and clarify areas of conflict between groups with differing visions for the future of rural communities.

Many states are currently undertaking research and extension efforts concerning these issues, and a regionally coordinated effort will produce more general tools and materials for all rural communities in the West. A group of researchers, extension specialists, and agency personnel from around the West attended a workshop entitled Federal Public Lands and Rural Communities in the West: Impacts and Alternatives, held in Tucson, Arizona, in early January 1995. The working group derived from workshop includes regional economists, range economists, rural sociologists, rural development council directors, and agency personnel from the USFS and the BLM from California, Oregon, Washington, Idaho, Nevada, Utah, Arizona, and New Mexico. What came out of this workshop is a team designated to write a regional proposal to use pilot communities throughout the West as test cases for a standardized data gathering, modeling, and educational effort. This allows for comparison of communities across states.

${ }^{6}$ Taken from a proposal to further research in the social sciences through use of existing continuing education structures, such as agricultural extension. Aaron Harp, rural sociologist at the University of Idaho, is the principle author of this proposal. 



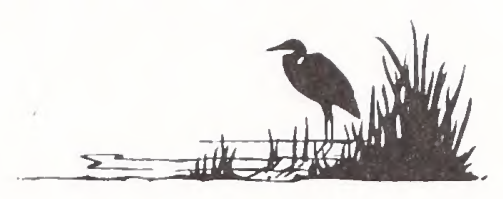

With this in mind, our objective is to utilize research and extension personnel throughout the West to accomplish the following goals:

1. Produce a set of impact methodologies and educational tools useful in states and communities across the West. The set of methodologies would focus on economic, social, and fiscal impact modeling and specification, and would involve university and state and federal agency personnel. The expertise in this area represented by the working group includes:

- Input/Output modeling;

- Computable General Equilibrium models;

- Econometric and Budget-based fiscal impact models;

- Qualitative and quantitative social impact assessment;

- Extensive and intensive data collection in regional and community settings, e.g., community measurement panels, telephone and mail survey techniques, focus groups, and personal interviews.

2. In the process of impact modeling, utilized Cooperative Extension models for community development, public issues education approaches, and participatory research methods to enhance the public understanding of impacts and how they are modeled.

3. Adapt existing education and training materials from the Western Rural Development Center to focus on public land issues. These would focus in the following areas:

- Environmental conflict resolution;

- Strategic planning;

- Business retention and expansion;

- Tourism assessment.

The result would be a shared system of methodologies, models and educational tools that would allow economists, sociologists and other social scientists to analyze, predict and evaluate changes to rural communities. It would provide a basis for negotiating the levels of acceptable change from the standpoint of the human dimension. Integration of the human factor in resource management decisions will help decision- makers make informed choices. Thus, development of a standardized system to gather and model rural communities will enable researchers, scientists, analysts and resource managers to establish common ground with the people most likely impacted by resource decisions-rural communities. 



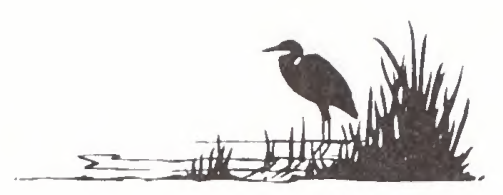

\section{CONCLUSION:}

Ecosystem Management has been described as a state of mind ${ }^{7}$. In other words, it is a way of thinking about how all matter and energy functions to sustain life and give it meaning. From the bacterium that breaks down the soil to the wide-eyed awe in a young child's face as he observes his first sunset, each part of the ecosystem needs to be seriously considered. Human society is no less important. How we fashion our questions largely determines the method(s) selected for analyzing and drawing conclusions that are meaningful and purposeful.

We are in the middle of a revolution, there are no longer sacrosanct institutions (reinvention is the current buzzword). Therefore, it behooves regional scientists to spend time thinking of ways to formulate the modern societial ecosystem questions and to develop new methodologies that will assist us in understanding the interrelatedness of humans to our environment. It is hoped that this paper has stimulated some to think more broadly and utilize the human capacity to formulate in the abstract and articulate in the concrete. Ecosystem management is a holistic framework of thinking that should never ignore the human factor. After all we are the ones who thought up the idea in the first place.

${ }^{7}$ Taken from Ecosystem Management: What Is It? by Allan E. Thomas, in Idaho Bureau of Land Management Technical Bulletin No. 94-5, April 1994. 



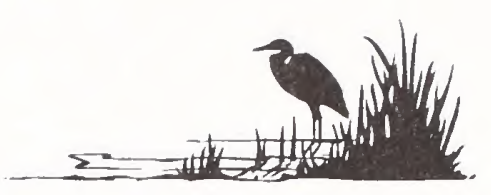

\section{REFERENCES:}

Boulding, Kenneth, The Economics of the Coming Spaceship Earth, Environmental Quality In a Growing Economy, Essays from the Sixth Resources For the Future Forum, Henry Jarrett Editor, Johns Hopkins Press, 1966.

Leontief, Wassily, "Quantitative Input-Output Relations in the Economic System of the United States," in The Review of Economics and Statistics, August 1936.

Miernyk, William H., The Elements of Input-Output Analysis, Random House, New York, 1965.

U. S. Department of Commerce, Economics and Statistics Administration, Bureau of the Census, Statistical Abstract of the United States, 1993, The National Data Book.

U. S. Department of the Interior, Bureau of Land Management, A Social, Economic and Fiscal Analysis of Custer and Lemhi Counties, Idaho: And Models, Technical Report in Fulfillment of Cooperative Agreement No. D-040-A-2-006, Idaho State Office, Boise, Idaho, March 1994.

The Idaho Fiscal Impact Projection Model (IDFIP): Base Line Results for Custer and Lemhi Counties, Idaho, Stephen C. Cooke and Scott Wolf, assistant professor and research associate respectively, Department of Agricultural Economics and Rural Sociology, University of Idaho, Moscow, Idaho.

The Custer-Lemhi County Economic Model (CLEModel): Overview, Results, Model Operation, and Documentation of Data Sources and Modeling Procedures, M. Henry Robison, Center for Business Development and Research, University of Idaho, Moscow, Aaron J. Harp, Department of Agricultural Economics and RuralSociology, University of Idaho, Moscow, Michael L. Lahr. USDA, Economic Research Service, Washington, D.C., Jon R. Freitag, Center for Business Development and Research, University of Idaho, Moscow, Idaho.

Using the Custer-Lemhi Economic Model (CLEModel) for Local Economic Impact Assessment: A How-To Manual, M.H. Robison, Senior Research Economist, Center for Business Development and Research, University of Idaho, Moscow, Idaho.

Evaluating Interlinkages In Custer and Lemhi Counties, Neil Meyer, Extension Economist, Policy and Rural Development, University of Idaho Cooperative Extension System, Moscow, Idaho. 



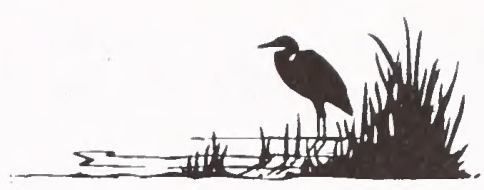

A Social Profile of Seven Communities in Custer and Lemhi Counties, Idaho, Aaron J. Harp, Teresa Pauley, Department of Agricultural Economics and Rural Sociology, University of Idaho, Moscow, Idaho.

U. S. Department of the Interior, Idaho Bureau of Land Management, Ecosystem Management, What is It? Achieving the New Land Ethic, A Framework Towards Ecosystem Management Performance Standards, Technical Bulletin No. 94-5, April 1994.

U. S. Department of the Interior, Bureau of Land Management and US Department of Agriculture, Forest Service, Eastside Ecosystem Management Project Charter, Interior Columbia River Basin Ecosystem Management Framework and Scientific Assessment and Eastside Oregon and Washington Environmental Impact Statement, January 1994.

U. S. Department of the Interior Bureau of Land Management and U. S. Department of Agriculture Forest Service, Record of Decision for Amendments to Forest Service and Bureau of Land Management Planning Documents Within the Range of the northern Spotted Owl, and Standards and Guidelines for Management of Habitat to Late-Successional and Old-Growth Forest Related Species Within the Range of the Northern Spotted Owl, April 1994.

Code of Federal Regulations, Part 2420 Multiple-Use Management Classifications, Subpart 2420 Criteria for Multiple-Use Management Classifications, 2420.2 Criteria, page 124, Public Lands: Interior, 43CFR Parts 1000 to 3999 Revised as of October 1, 1994. 



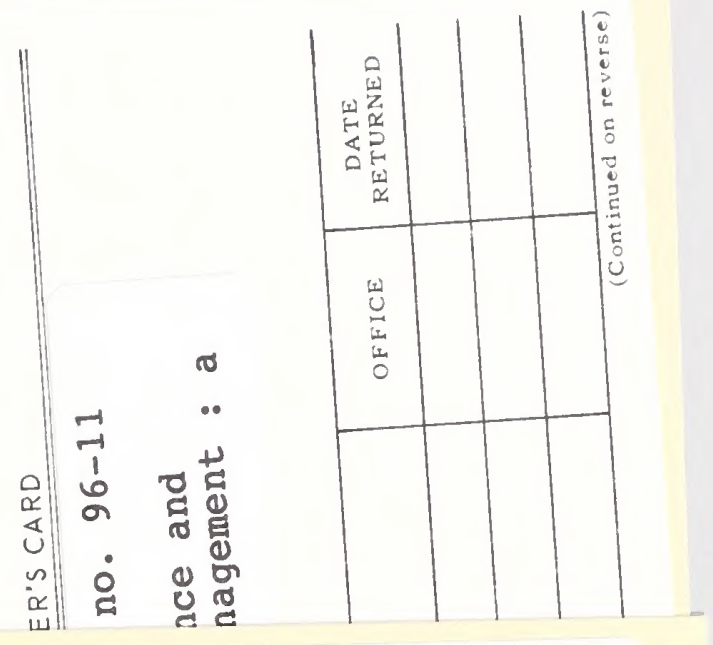

QL 84.2 .L352 no. 96-11

88055393

Regional science and ecosystem management : a

BLDG 50, ST-150A

DENVER FEDERAL CENTER P.O.BOX25047 DENVER, COLORADO 80225 


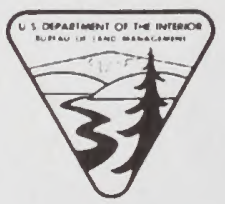

Bureau of Land Management

Idaho State Office

3380 Americana Terrace

Boise, Idaho 83706

\section{BLM/ID/PT-96/020+1150}

